\title{
RELIGIÃO, POLÍTICA, GUERRA E MULHERES (CONGO E ANGOLA, SÉCULOS XVI E XVII)
}

HEYWOOD, Linda M. Jinga de Angola, a rainha guerreira da África. Tradução de Pedro Maia Soares. São Paulo: Todavia, 2019. 320p.

SOUZA, Marina de Mello e. Além do visivel: poder, catolicismo e comércio no Congo e em Angola (séculos XVI e XVII). São Paulo: Edusp/ Fapesp, 2018. 320p.

$\stackrel{\prime}{E}$ extremamente oportuno quando duas excelentes obras afins e complementares vêm a lume no mercado editorial brasileiro, quase no mesmo ano, o que revela um momento ímpar de historiografia internacionalizada e conectada. Ganha-se nos detalhes e em visão de conjunto. Uma obra de cada vez, porém.

Jinga de Angola, a rainha guerreira da África, ${ }^{1}$ de Linda Heywood, professora da Boston University, analisa uma personagem que merece lugar de relevo na historiografia. Ainda que seja conhecida por especialistas, e esteja presente em folguedos populares brasileiros e no cinema angolano, por exemplo, o papel central da rainha guerreira que pôs em xeque as conquistas

1 Do original em inglês Njinga of Angola: Africa's Warrior Queen, Harvard: Harvard University Press, 2017. portuguesas na África Central Atlântica deveria ser mais notório. Com efeito, Jinga estremeceu o Atlântico Sul português, caso se dê crédito à famosa sentença do padre seiscentista Antônio Vieira segundo a qual "sem Angola, não há negros e sem negros não há Pernambuco". Faz até postular se, em suas alianças com os holandeses em meados do século XVII, houve, por parte da guerreira ambunda, bem como pelo rei do Congo, alguma visão geopolítica sobre a debilidade das conquistas lusas justamente no momento da chamada "viragem atlântica". Então, a monarquia pluricontinental portuguesa, cabe lembrar, envolta na Guerra dos 30 Anos, sentia pesadas perdas no oriente, invasões holandesas no Brasil etc. Tudo isso em meio ao domínio espanhol e à consecutiva afirmação da nova dinastia portuguesa dos Bragança em desacordos 
com o papado. Decerto, o livro não se ocupa da geopolítica europeia e da monarquia portuguesa, mas redimensiona o impacto político da rainha Jinga no Atlântico Sul e na correlação de forças dos estados europeus da época moderna. $\mathrm{O}$ ocaso das monarquias ibéricas como potências de primeira ordem deve um pouco às guerras angolanas capitaneadas por Jinga. Os especialistas em história moderna ganhariam mais se mirassem, tal como atenta Heywood, para essa história que Antonio de Cadornega narrou há quase quatro séculos.

Ademais de lição de método, é talvez a mais completa biografia histórica sobre a rainha africana, plena de detalhes sobre suas experiências afetiva, familiares, de gênero, religiosa, política etc. Vai-se, para usar termos em voga, do micro ao macro com extrema facilidade. Com certeza, a pesquisa não será a última palavra sobre a personagem, mas, sem dúvida, é a mais integral até hoje, não apenas pela variedade de documentos abarcados, mas, sobretudo, pela arguta explanação. Tal resultado só é possível aos que têm larga experiência no ofício da História. Assim, o livro é, a um só tempo, biografia histórica, história de gênero, história moderna, história da África, dos sertões do que veio a ser Angola, do Atlântico, do Brasil, de tudo isso, formando um conjunto integrado. Na obra, o leitor adentrará nas vidas política, diplomática, militar, religiosa dos povos ambundos, ligadas aos imbangalas, todas imbricadas entre si e narradas a partir da trajetória de vida da rainha do Ndongo e de Matamba.

A narrativa que alude à criação do reino do Ndongo e aos antepassados reais de Jinga demonstra que aquelas histórias não se encerram com a morte da rainha em 1663, posto que seus ritos fúnebres foram objeto de disputa político-religiosa entre os partidários do catolicismo e os de religiões africanas nativas, ambos os lados cientes de que os legados de Jinga mesclavam política e religião. Todos sabiam que fé e poder eram indissociáveis, como também aponta Marina de Mello e Souza, mas em Heywood as heranças da rainha ademais se observam em outros sentidos. As memórias e as imagens arquitetadas sobre a personagem foram alvo de controvérsias na época em que viveu, bem como nos séculos XVIII e XIX, nas páginas da historiografia salazarista, na edificação da memória no pós-independência de Angola e, igualmente, na América portuguesa e no Brasil imperial e republicano, onde Jinga nunca pisou, mas vive em folguedos populares como as congadas. $\mathrm{Na}$ abordagem de Heywood (cujo livro também é uma reconstrução da imagem da personagem), temos uma autora que enfatiza questões de gênero, o que não é muito comum nas biografias sobre Jinga. ${ }^{2}$

2 Sobre outras autoras que, direta ou tangencialmente, pesquisaram Jinga, cf. Beatrix Heintze, Fontes para a história de Angola do Século XVII. Memórias, relações e outros manuscritos da coletânea documental 
Sem que eu queira dizer que uma excelente obra sobre Jinga tenha de ser escrita por mulheres, o livro é uma aula sobre o papel feminino na história da África em suas relações com conquistadores europeus modernos, especialmente nas teias estabelecidas com poderes portugueses, enredo permeado de guerras, comércio, escravização, resistências, diplomacias e trocas religiosas e culturais. $\mathrm{O}$ feminino, mesmo que vestido de masculino, como foi o caso de Jinga em boa parte de sua vida de guerreira jaga (ou imbangala), atuou decisivamente em todas aquelas searas. Desse modo, se o papel de uma pessoa extremamente poderosa em certos momentos da história é decisivo para a condução e o desfecho dos processos e para os sentidos vindouros, fez alguma diferença o fato de Jinga ter sido a mulher que foi?

de Fernão de Sousa, Sttutgart: Franz Steiner Verlag Wiesbaden GMBH, 1985 (vol 1), 1988 (vol 2). Disponível em http:// memoria-africa.ua.pt/Library/ShowImage. aspx?q=/Angola/FontesParaAHistoriaDeAngola-01\&p=9; Angola nos séculos XVI e XVII. Estudos sobre fontes, métodos e história, Luanda: Kilombelombe, 2007; Selma Pantoja, Njinga Mbandi. Mulher, guerra e escravidão, Brasília: Thesaurus, 2000; Marina de Mello e Souza, Além do visivel: poder, catolicismo e comércio no Congo e em Angola (séculos XVI e XVII), São Paulo: Edusp/Fapesp, 2018; Mariana Bracks Fonseca, "Jinga de Angola: memórias e representações da rainha guerreira na diáspora" (Tese de Doutorado, Universidade de São Paulo, 2018). Ver ainda o livro, entre nós pioneiro, de Roy Arthur Glasgow, Nzinga: resistência africana à investida do colonialismo português em Angola (15821663), São Paulo: Perspectiva, 1982.
A questão de gênero é central na investigação de Linda Heywood. Novamente aqui, trata-se de história da África conectada à história europeia durante a época moderna, do "lugar das mulheres na política na África e no mundo" (p. 9). Ao ressaltar a função feminina na política no Ndongo, terra natal da guerreira, em Matamba, mas também nos kilombos imbangalas, Heywood salienta que o rei do Ndongo, Ngola Mbande, irmão de Jinga, era figura sombreada pela poderosa irmã, mesmo quando ela ainda não encabeçava o poder. A par e talvez mesmo por isso, para consolidar-se como rei, o irmão assassinou o filho de Jinga e a esterilizou, tal como procedeu com as outras irmãs. Dizia-se que quem é rei não tem parente!

Todavia, uma vez derrotado militarmente pelos portugueses, Ngola Mbande se valeu do prestígio da irmã entre os ambundos e a enviou como diplomata aos que o venceram. A partir daí, Jinga atuou decisivamente sobre a vida política da África Central. Na ocasião, 1622, por volta de seus 40 anos de idade, seu batismo em Luanda e o famoso episódio em que se sentou em uma escrava-cadeira ganharam importantes conotações simbólico-políticas. Sentar-se sobre uma escrava significou não se deixar colocar, no palco da negociação política, em plano inferior ao governador português em uma cadeira. Ao longo da vida, esta atitude de Jinga expressou sua perspectiva de nunca render tributo aos portugueses porque 
ela se considerava rainha do estado soberano do Ndongo. Antes disso, o batismo da - ainda diplomata Jinga e o de suas irmãs, mas não o do seu irmão, rei do Ndondo, havia selado o compromisso do envio de tropas portuguesas contra Cassanje, acordo de resto não cumprido.

$\mathrm{Na}$ política interna do Ndongo, Jinga aconselhou com êxito o seu irmão a não se deixar batizar porque a adesão ao rito cristão seria lido como submissão política pelos portugueses. Depois de morto o rei, supostamente envenenado pela irmã, Jinga ascendeu ao poder no Ndongo, em 1624, que então era uma sombra daquele da época de seus avôs, quando ela era ainda jovem. Almejando reconstruir o passado exitoso do reino em honra a seus antepassados, durante o seu reinado, de 1624 a 1663, Jinga pelejou para reconstruir "a hegemonia do Ndongo e limitar o poder português na região" (p. 61).

É a partir daí que Linda Heywood constrói a vida de Jinga em prol da consolidação da liderança política ambunda e em oposição ao processo de conquista portuguesa, tudo permeado por alianças e conflitos com outros poderes na África Central Atlântica, nomeadamente com o reino do Congo, o Dembo, os imbangalas, Cassanje, e com os holandeses. Conhecedora das tradições ambundo, exímia oradora, estrategista militar, seu prestígio e poder eram realçados, não só por descender do rei do Ndongo - de quem seria filha com sua principal concubina, Kasenda -, mas também por seus atributos pessoais. Ao perceber a impossibilidade da lida com os portugueses apenas pela via diplomática, a rainha ambunda fortaleceu elos com imbangalas, ou seja, aderiu aos seus ideais guerreiros, que abrangiam canibalismo, infanticídio, sacrifícios humanos nos ritos fúnebres (tambos). Ao adentrar tais ritos, Jinga fundiu, política e religiosamente, tradições ancestrais ambundas com ethos guerreiros imbangalas. Fé, ritual e poder eram intercambiáveis também para sociedades centro-africanas, à revelia do cristianismo, como observa Heywood.

Tal percurso levou Jinga à fuga estratégica para leste, do Ndongo a Matamba, e a uma aliança com sociedades imbangalas, sobretudo Cassanje, a quem teve que ceder. A contra-ofensiva lusa colocou um aliado no trono do Ndongo, Ngola Hari, adversário de Jinga. No confronto entre ela e poderes portugueses, por cerca de 30 anos assistiu-se ao jogo das pressões diplomáticas e militares de parte a parte, com oscilações políticas de sobados, dembados e dos reinos do Congo e de Cassanje, que ora estavam ao lado de Jinga, ora dos portugueses. Aqui talvez fosse o caso de afirmar que a guerra era a continuação da política por outros meios porque muitos dos embates tinham fins políticos. Talvez também coubesse à autora salientar aspectos das culturas políticas da África Central que permitiam oscilações de vínculos políticos e a não separação de estratégias diplomáticas e militares. 
Não obstante tal lacuna, Heywood demonstra que, no instável xadrez político do Atlântico centro-africano, Jinga sabia que para ser líder política também precisava ser líder espiritual. Pois era um mundo muito distante da laicização do poder, tal como na Europa, em demais partes da África ou nas Américas. A aproximação da rainha ambunda, confrontada no poder pelo aliado dos portugueses, Ngola Hari no Ndongo, conduziu-a em direção aos rituais imbangalas. Porém, apesar de batizada, e "imbangalada", ela nunca deixou de lado "as próprias crenças religiosas, nem os rituais tão essenciais para a elite governante de Ndongo e para os ambundos comuns" (p. 81). Jinga até tentou, no início de seu reinado, em 1625-1626, abrir seu reino ao cristianismo, mas a conversão cristã era essencial para a política de domínio portuguesa em Angola. Governadores, jesuítas e outros portugueses consideravam a propagação do cristianismo católico, sob controle português, como aspecto basilar de seu projeto colonial. Mesmo assim, os poderes portugueses não confiavam em Jinga, e chegaram a pensar que ela agia mais “"por medo do que por devoção"” (p. 84), leia-se, mais por estratégia de poder do que por devoção cristã.

Além de vedado o caminho estrito da diplomacia cristã, tinha o agravante de gênero. A cultura política europeia, em especial a ibérica, afirma Heywood, não lidava bem com a primazia feminina na condução da política. Por exemplo, o governador Fernão de Sousa instou um seu aliado a desqualificar Jinga perante aliados da rainha com o argumento, entre outros, de que ela " "não era uma rainha, nem podia ser, por ser mulher"” (p. 92). Sob suas próprias condições, Jinga até se propôs a ser vassala dos portugueses, mas a recusa recebida revela que eles se calcavam em uma cultura política na qual a esmagadora maioria das mulheres das famílias europeias se contentava com estarem à margem da liderança política. Para Heywood, Sousa era desconhecedor da cultura política do Ndongo, na qual "as mulheres tinham um papel político na governança" (p.104). O caso da rainha Elizabeth da Inglaterra pós-reforma protestante era uma exceção à regra, mas uma exceção que não estava na península ibérica católica de Sousa.

Todavia, há alguns senões a esta diferença sugerida pela autora. Para além do silêncio sobre a oposição do próprio irmão de Jinga ao direito de uma mulher ascender ao trono, o que atenuaria a ideia de que a cultura política ambunda tolerava o governo feminino, a autora não menciona outras personagens europeias à frente do poder político, como, por exemplo, Isabel de Castela, na Espanha, Catarina de Médici, na França, Mary I, na Escócia, ou mesmo Maria I, em Portugal de fins do século XVIII.

Contudo, teria sido em contraste com a acepção misógina portuguesa que emergiu a aliança de Jinga com 
os holandeses, entre 1641 e 1648 , e a montagem de uma aliança centro-africana contra os lusos que abrangia o Reino do Congo e outros Estados nominalmente independentes. Mais importante, porém, foi a decisão de Jinga de aderir a rituais imbangalas combinando-os com as tradições ambundas. A partir daí, foi criada uma "nova ideologia que se baseava na inversão de categorias de gênero e novos ritos religiosos e seculares" (p. 120). Essas atitudes deram uma feição peculiar à rainha guerreira, fazendo dela uma figura lendária entre africanos e europeus, ainda em vida.

Não obstante Heywood insistir nas marcantes diferenças entre as culturas políticas ibéricas e centro-africanas em torno do papel feminino, deve-se refletir sobre este aspecto também pelos vieses político e religioso. Por exemplo, aliada ao Congo em 1648, Jinga enviou tropas para debelar uma rebelião em uma província liderada por um governante centro-africano. Além de socorrer um aliado, Jinga nutria sentimentos pessoais para esta batalha porque aquele governante teria dito que "ela não passava de uma mulher que era "mais hábil com uma roca do que com uma espada"' (p. 162). Talvez Jinga não pudesse ser diminuída por ser mulher, sob pena de sair enfraquecida naquele contexto conturbado. No entanto, relativiza-se a rígida diferença relativa ao feminino entre culturas políticas ibéricas e centro-africanas, tendo em vista a argumentação misógina do governante centro-africano que lhe era hostil.

Nesse sentido, até que ponto, tal como Elisabeth e outras mulheres na Europa, Jinga também não foi uma exceção na África Central? O poder não seria visto como atributo masculino entre ambundos e imbangalas? Lembremos que ela foi a primeira mulher governante do Ndongo e também a primeira líder a governar Matamba, um Estado imbangala, aderindo ao estilo jaga de mando. Como afirmou a própria autora, ao adentrar as leis da kizila imbangalas, Jinga queria "encontrar seu lugar em um mundo onde as mulheres raramente tinham papel importante na guerra, na política e na diplomacia" (p. 129). De fato, ela rompeu tradições políticas de governos masculinos em duas sociedades centro-africanas. Mas parece que o governo feminino em Matamba terminou com sua morte, já que sua irmã Bárbara, resgatada dos portugueses, a quem ela pretendia fazer sua sucessora, foi assassinada.

Até certo ponto, para tornar-se líder imbangala, e talvez por isso mesmo, foi necessária uma importante inversão de gênero. A rainha decidiu que seu círculo interno e seus seguidores a considerassem homem, e não mulher. Ela iniciou sua transição de gênero, porém, casando-se com um homem, Ngola Ntombo (Senhor Ntombo), mas mandou que ele se vestisse como mulher. Jinga se referia a ele no feminino e exigia que se dirigisse a ela como rei, não como rainha. Ao casar, ela ampliou 
o número de seus concubinos, aos quais também se referia como mulheres e também lhes ordenou que se vestissem com as mesmas roupas de suas guarda-costas femininas. Igualmente, ordenou que os concubinos dormissem nos mesmos quartos de suas guarda-costas, mas sem relações sexuais. Se se tocassem, mesmo acidentalmente durante o sono, "seriam mortos ou reduzidos a impotentes ou inférteis" (p.132).

Essa inversão de gênero foi crucial para tornar Jinga uma líder imbangala, posto que precisasse, ou quisesse, ser considerada como homem, até mesmo adotando a poligamia, não a poliandria, já que seus concubinos eram tidos por mulheres. Logo, novamente incumbe uma relativização das diferentes culturas políticas (europeia e centro-africana) sobre mulheres e poder. Se para se tornar líder imbangala, Jinga necessitou travestir-se em homem, e seus concubinos em mulheres, a representação simbólica do poder político não seria masculina? Atenua-se, novamente, a diferença entre as culturas políticas europeias e centro-africanas? Até certo ponto, sim, o que mereceria uma atenção maior de Heywood. Ou foi uma mudança de gênero de fachada? Tudo sugere que não, parecendo ter razão a literatura de ficção de Pepetela: o escravo narrador de $A$ gloriosa família dizia "o meu rei Jinga”. Diferente de Jinga, na África Central Atlântica as mulheres sentavam-se no chão, exceto a "rainha Jinga, que sentava em cadeirões ou nas costas dos escravos, mas essa era rei". Jinga se considerava "rei, porque só o rei manda, e ela não tem nenhum marido que mande nela, ela é que manda nos muitos homens que tem no seu harém e que chama de minhas esposas. É Rei Jinga Mbandi e acabou". ${ }^{3}$ Enfim, ela não desempenhava papel de mulher e a representação do poder, portanto, era masculina.

Por outro lado, há uma dimensão religiosa que pode elucidar a questão ou adicionar novas explicações, o que poderíamos denominar de inversão espiritual de gênero, sem perder de vista que espiritualidade e política andavam juntas em sociedades centro-africanas. Por exemplo, em fins do século XVI o padre jesuíta Barreira entrevistou uma importante autoridade espiritual, um ganga, de uma província, a quem creditavam poderes para controlar o clima etc. O padre se alarmou com $o$ aspecto do ganga ao perceber que ele parecia "estar vivendo como uma mulher, pelo menos exteriormente". Seus cabelos eram longos e soltos, e ele se vestia com "panos normalmente usados somente por mulheres". Indagado pelo jesuíta, o ganga revelou que nascera "homem, mas o

3 Pepetela, A gloriosa família. O tempo dos flamengos, Rio de Janeiro: Nova Fronteira, 1999, p. 96, 87, 23. Sobre a literatura histórica de Pepetela, vide Robson Dutra, "Quem tem medo de história? Os romances de Pepetela e a cartografia de Angola", in Adriana Campos e Gilvan V. da Silva (orgs.), Da África ao Brasil. Itinerários históricos da cultura negra (Vitória: Flor e Cultura, 2007), pp. 275-291. 
'demônio' dissera à sua mãe que ele morreria imediatamente se não 'se tornasse uma mulher"' (p. 39).

A se dar crédito ao padre Barreira, pode ser que a inversão espiritual de gênero, em Jinga, propiciasse parâmetros para sua inversão política de gênero, pois religião e política eram indissociáveis. A inversão espiritual de gênero foi constatada empiricamente por Linda Heywood, que talvez pudesse relacioná-la à questão política mais a fundo. Mas isto não diminui a novidade de sua análise. Ao contrário, abre sendas para novas pesquisas.

Idosa(o), cansada(o) de guerra, novamente Jinga fez uma conversão político-religiosa de gênero quando das negociações diplomáticas para o resgate de sua irmã, refém dos portugueses, com vistas à sucessão em Matamba. No processo de cristianização iniciado na virada da década de 1640 para a de 1650 , Jinga abandonaria paulatinamente rituais ambundos e imbangalas, mesmo sob risco de perder apoio político interno, mas nem por isso deixou de batizar com nome feminino cristão, de construir igrejas católicas, de consentir a pregação de padres cristãos, com o capuchinho Gaeta à testa, de disseminar a cruz etc. Mais ainda: a rainha casou cristãmente com um homem, androginando-se, e teria até desejado, com vistas à sua sucessão do poder em Matamba, o milagre da maternidade na casa dos seus 75 anos de idade, milagre que Gaeta não garantiu. Esta segunda conversão de Jinga, portanto, também foi um ato político, mas nem por isso menos religioso. Através dos capuchinhos, ela aproximou-se de Roma para se distanciar da tutela religiosa do padroado português (capítulos 6 e 7), tal como fizera o reino do Congo no século anterior. Como salienta Marina de Mello e Souza, o cristianismo conguês foi instrumento de afirmação política da elite local, era uma religião de Estado à revelia dos portugueses e do clero tradicional africano.

Nesse sentido, quais os modelos de Jinga para sua conduta política no cenário centro-africano nos anos finais de sua vida? Todos os procedimentos de negociação de Jinga para o resgate da irmã contaram com os diplomatas capuchinhos enviados por Roma, a par dos jesuítas. $\mathrm{O}$ episódio gerou desavenças entre a câmara de Luanda e o governador de Angola, Sousa Chichorro. Para Roma, o Conselho Ultramarino, os capuchinhos encabeçados por Gaeta e Cortona, o Reino do Congo ou os poderes imbangalas, incluindo Cassanje, o resgate de uma das irmãs de Jinga não foi alheio a nenhum desses agentes políticos, e nem ao rei português, cuja carta de apoio à câmara luandense, avessa ao acordo, chegou tarde. O rei de Portugal se aliou à poderosa câmara, mas, como demonstra Marina de Mello e Souza, o governador de Angola, contrariando seu rei, já havia se aliado aos capuchinhos e iniciado o processo de negociação antes da chegada da missiva. No resgate da 
irmã de Jinga estavam em jogo, pelo lado português, a possibilidade de dobrar a rainha e, do lado da guerreira, a de fortalecer seu poder e preparar sua sucessão.

Mas o principal modelo da rainha de Matamba não era nenhum daqueles atores no quadro geopolítico centro-africano e europeu; em sua segunda conversão, a questão dos tributos em escravos (componente sempre primordial nas contendas entre europeus e africanos, amiúde entre os próprios africanos) não seria resolvida ao modo português; e tampouco ela deixou de requerer as antigas terras do reino do Ndongo, que reclamava como suas. O leitor compreenderá nos capítulos 6 e 7 que, ao contrário do que se supõe, nem sempre a adesão ao cristianismo implicava submissão política, e o modo como Jinga regeu o processo se torna compreensível dentro dos horizontes políticos e da religiosidade ambundos, como nos deixa ver Linda Heywood.

O modelo político feminino de Jinga que o leitor se deleitará em descobrir também é muito bem perscrutado pela autora - mas será que, no fim da vida, Jinga teria se inspirado no Reino do Congo, que se aproximou de Roma para frear o poderio do padroado português? Seja como for, não houve o menor problema para Dona Ana de Sousa, o nome de batismo de Jinga, retomar sua identidade de gênero original. Tampouco o cristianismo na África Central, no Ndongo, em Matamba, alhures, contrariava sempre a religiosidade tradicional ambunda, que primava em trocar ou mesclar símbolos rituais de acordo com as conveniências político-religiosas, cujas razões são muito bem trabalhadas pela autora. Afinal, a imbricação entre política e religião precisou manipular símbolos e ritos. Jinga encarnou e desencarnou tudo isso.

Se Linda Heywood enfatiza a trajetória de vida de Jinga, o livro de Marina de Mello e Souza dá relevo ao pluralismo do cristianismo católico em sociedades centro-africanas. Didaticamente, o livro, fruto de uma pesquisa de dez anos, coroa a trajetória acadêmica de uma pesquisadora madura. Além da abordagem sobre os significados religiosos da cruz para povos centro-africanos, Marina Souza revisita o tema do cristianismo no Congo, objeto de um importante trabalho anterior de sua autoria, ${ }^{4} \mathrm{e}$ acrescenta Dongo, a região dos Dembos e Matamba na abordagem comparativa.

A autora avalia o impacto do Reino do Congo quinhentista para a mudança de orientação da administração portuguesa na África Central Atlântica seiscentista. A partir daí, aborda o cristianismo católico dos séculos XVI e XVII, quer como foi politicamente vivenciado, quer a ação missionária de padres católicos, sobretudo os capuchinhos. A comparação de diferentes sociedades centro-africanas lança uma

4 Ver Marina de Mello e Souza, Reis negros no Brasil escravista. História da Festa de Coroação do Rei Congo, Belo Horizonte: Editora UFMG, 2002, entre outros títulos seus. 
perspectiva instigante sobre as diferenças e semelhanças do catolicismo no Congo e nas demais searas.

No Congo, o catolicismo, que segundo a expectativa portuguesa deveria ter sido instrumento de controle político, redundou em uma vertente autônoma devido ao modo pelo qual aquela religião foi apropriada pela sociedade conguesa, que se valeu de suas próprias estruturas religiosas para implementá-la. Estreitando relações com Roma, desde cedo os reis do Congo invocaram sua condição de cristãos para manter autonomia perante Lisboa e o padroado português. Os portugueses contavam com a submissão africana para fazer face à presença holandesa na região nos momentos iniciais da dinastia de Bragança, quando da restauração, em 1640, do trono português então sob controle espanhol. $\mathrm{Na}$ época, Portugal estava em conflito com o papado, que pendia para o lado espanhol. Nessa mesma altura, as elites políticas do Congo reforçaram, via cristianismo, seu poder diante de seus concorrentes, mormente os religiosos, valendo-se do próprio catolicismo para sua a legitimação.

Desta maneira, o que do ponto de vista da administração portuguesa deveria ser um instrumento de dominação no Congo, como ponta de lança para toda a África Central, tendo em vista a influência deste reino sobre outras sociedades centro-africanas, acabou por reforçar, sob novas bases, o poder conguês diante de outras sociedades e da própria governança portuguesa.
De um modo ou de outro, porém, no livro de Mello e Souza, tal como em Heywood, religião, fé e comércio (sobretudo de cativos), a tríade basilar do contato entre europeus e africanos, andavam juntas e misturadas. A historiadora foca nos catolicismos europeus (jesuíta e, sobretudo, capuchinho), suas variantes em África Central Atlântica e, principalmente, nas experiências e apropriações do catolicismo por parte de sociedades africanas. Ela rompe definitivamente com a ideia de um catolicismo monolítico na região, bloco homogêneo quebrado no século XVII pelos poderes africanos e por desavenças entre jesuítas representando o padroado régio e capuchinhos a serviço do papado.

Com o fracasso do projeto de religião como instrumento de produção de súditos no Congo, desconfiadas do clero nativo e do clero romano representado pelos capuchinhos, as autoridades portuguesas puseram as armas à frente da fé em sua lida com outros povos centro-africanos. Daí resultaram muitos conflitos de portugueses contra Dongo (Ndongo), Matamba e na região dos Dembos. Mas, a par das armas, nada significa que a geopolítica da África Central Atlântica se livraria das questões de fé. Porém, aqui cabe indagar se efetivamente a experiência quinhentista de conversão da elite do Congo propiciou um saber acumulado de conquista portuguesa entre a dinastia de Avis, o domínio dos Felipes e a afirmação 
da nova monarquia de Bragança. ${ }^{5}$ Essa questão, entretanto, não reduz o valor da abordagem comparativa da autora sobre os conflitos e aproximações entre sistemas religiosos distintos na região africana.

Para compreender o pluralismo do catolicismo, Marina de Mello e Souza entende que é preciso adentrar as estruturas religiosas das sociedades africanas que permitiram-nas interpretar a religião europeia a partir de seus próprios interesses. Nesse esforço, a autora dialoga com uma vasta bibliografia especializada. Este diálogo, combinado ao manuseio de relatos de época e de trabalhos antropológicos baseados na história oral, conduziu a historiadora a uma seara já fartamente trilhada por estudiosos, mas, mesmo assim, e quiçá por isso mesmo, essa opção lhe deu base para propor novas explicações sobre os significados de elementos sagrados centro-africanas e sobre as inseparáveis interconexões entre fé, política e comércio, ou seja, buscando enxergar Além do visível, feliz título do livro.

5 Ausências de projetos, de ordenamento unidirecional, reorientações de sentido e pragmatismo ao acaso foram comuns na expansão portuguesa. Vide, entre outros, Luis Felipe Thomaz, De Ceuta a Timor, 2a. ed., Lisboa: Difel, 1998; António Manuel Hespanha, "A constituição do império português. Revisão de alguns enviesamentos", in João Fragoso, Maria de Fátima Gouvêa e Fernanda Bicalho (orgs.), O Antigo Regime nos trópicos. A dinâmica imperial portuguesa (Rio de Janeiro: Civilização Brasileira, 2001), pp. 163-188.
Compreender o mundo dos mortos africanos é um exercício que percorre toda a obra e leva à explicação do mundo político-social dos vivos. O que está além do visível no Congo, no Dongo, em Matamba nos séculos XVI e XVII é percebido através de certos signos, a começar pela cruz cristã. Se para a monarquia portuguesa, a cruz nas áreas de conquista simbolizava conversão e conquista, ou, como afirmara Charles Boxer, em quem a autora se assenta, “"a inseparável relação entre cruz e coroa, trono e altar, religião e império"' (p. 27), eram outras as acepções centro-africanas. Aqui, porém, vale uma ressalva.

Ao enfatizar a instrumentalização da religião católica pelas monarquias ibéricas, sobretudo a portuguesa, como meio de conquista, a análise de Marina Mello e Souza deu pouco relevo aos traços sacro-políticos do próprio catolicismo europeu. Destarte, ao comparar as relações "entre o poder político e a religião nos dois universos, o europeu e o centro-africano", afirma que, embora semelhantes em essência, "eram extremamente distintas" (p. 12). A natureza do poder político europeu tenderia cada vez mais a se "separar da esfera religiosa e aproximar-se dos interesses relativos à dimensão material da vida humana, ou seja, à esfera a economia" (p. 12), ao passo que a natureza do poder político centro-africano se guiava pela "perspectiva que integrava os homens a um contexto maior do qual eram indissociáveis, e fortemente apoiado na esfera simbólica" (p.13). Ancorada principalmente na obra de Boxer 
sobre a Igreja católica militante, a autora passou ao largo da vasta e sólida historiografia sobre Igreja católica, bem como as manifestações da segunda escolástica no mundo ibérico e nas áreas de conquista. Contudo, certamente esta ausência se deveu à opção por compreender o catolicismo pela ótica das sociedades africanas, objeto principal do livro.

E só a partir daí foi possível inovar na interpretação dos significados da cruz e de outros símbolos do sagrado centro-africano, ponto alto do livro já em seu primeiro capítulo. Após discorrer sobre a organização político-social conguesa associada à esfera do sagrado (procedimento de cada capítulo/sociedade abordada), Souza enfatiza as três esferas do mundo invisível: a dos ancestrais, a dos mbumba e a dos nkadi mpemba. A primeira era formada pelos chefes fundadores de linhagens e abrangia dimensões míticas. A eles eram dedicados cultos em seus túmulos pelos principais de cada linhagem. A dimensão mbumba contemplava os espíritos da terra e da água, ligava-se ao território e à fertilidade, e seu culto era da alçada do kitome (sacerdote). Por fim, a esfera nkadi mpemba se imbricava ao mundo social, ao poder de proteção e cura, mas igualmente à destruição. Seu sacerdote era o ganga, que operava através dos minkisi (objetos rituais) para fins de adivinhações, curas, julgamentos etc. $\mathrm{O}$ poder no Congo devia ser legitimado por estas três dimensões.

Contudo, ainda em fins do século $\mathrm{XV}$, o mani do Congo e o mani da província do Soyo foram batizados no catolicismo, o que foi visto de forma diferente pelo clero católico e pelos centro-africanos. Os primeiros liam o batismo como conversão, e por isso Roma e Portugal aceitavam o Congo como um reino cristão, mas os segundos o liam a partir de suas crenças tradicionais associadas a ritos e objetos de culto católicos. Em poucas palavras, alicerçada em farta literatura antropológica, Marina Souza grifa a ampla capacidade de religiões centro-africanas em incorporar, e mesmo substituir, símbolos sagrados de outras religiões, decodificando-os a seu modo - o que, aliás, não deve causar estranheza aos cristãos, posto que a cruz antecede à crucificação de Cristo.

É tentador expor ao leitor a sagaz interpretação que Marina de Mello e Souza fornece da incorporação de símbolos cristãos pelos congueses quinhentistas, principalmente a cruz, mas seria um spoiler. Garanto, todavia, que depois da leitura da obra qualquer cristão ou estudioso do cristianismo nunca mais olhará para a cruz do mesmo jeito, e também repensarão a importância dos sonhos, atentarão ao movimento religioso circular anti-horário da vida e da morte em torno da cruz, à matéria de que as cruzes são feitas, seu lugar nos altares, às procissões etc. Mais do que um diálogo de surdos, o catolicismo simbolizado na cruz no Congo estabeleceu uma convergência de concepções europeias e centro-africanas. A cruz no Congo estava ligada ao poder, fundamentando-o sob novas 
bases, mas sem romper em nada com o tradicional sistema religioso conguês. Entretanto, ao que tudo indica, a convergência se limitava à absorção de símbolos católicos por parte das culturas religiosas centro-africanas. Aqui cabe uma questão que talvez possa valer para toda a obra. Se o sistema religioso centro-africano permitia e viabilizava a incorporação e/ou a substituição de símbolos sagrados, de que maneira os bacongos, os ambundos, e mesmo os jagas, observaram a queima e a destruição, por parte de padres europeus, do que chamavam de "ídolos"? Liam-nas como parte de um processo substituição de símbolos sagrados para acomodar a nova religião? Marina de Mello e Souza não faz esta indagação, mas só cheguei a ela a partir do seu livro, repleto de exemplos de tal natureza retirados de uma leitura atenta e minuciosa de cronistas religiosos e militares já há muito utilizados pela literatura especializada. Dessa maneira, a autora ensina que é sempre possível ao historiador inovar na leitura de documentos e relatos já bastante conhecidos. O livro, de fato, estimula novos caminhos para futuras pesquisas.

A "nova" base religiosa do poder no Congo viabilizou o estreitamento dos laços do reino do Congo não apenas com Lisboa, mas, principalmente, com Roma. A elite conguesa enviou seus filhos para serem ali educados e desviou-se do padroado régio calcado mormente nos jesuítas. Se, de um lado, a monarquia portuguesa visava criar um novo Portugal no Congo, até em termos de prática escrita de registro do poder, ou melhor, almejava uma "lusitanização do Congo" (p. 74), no final predominou, lato sensu, uma apropriação da escrita pelos africanos ${ }^{6}$ estabelecida sobre estruturas político-religiosas próprias incapazes de dissociar o mundo dos vivos do mundo invisível.

Chave para os demais, o capítulo 1 analisa as imbricações entre religião, poder e vida social em culturas centro-africanas, especialmente no Congo do século XVI, onde a incorporação de elementos do catolicismo serviu a interesses políticos congueses, quer no fortalecimento do poder de sua elite perante poderes locais religiosos, quer perante seus aliados, quer nos momentos de sucessão, quer, sobretudo, na legitimação do poder do mani Congo e na edificação de uma religião de Estado.

Os demais capítulos, quase sempre referidos no primeiro, completam a visão de conjunto de sociedades da África Central Atlântica dos séculos XVI e XVII, excluída Benguela, mais ao Sul. No capítulo 2, a autora aborda a conquista/construção de Angola sobre partes do Dembo e do outrora "Ndongo como estado independente" pelos portugueses associados a

6 Ana Paula Tavares e Catarina Madeira Santos, Africae Monumenta. A apropriação da escrita pelos Africanos, Lisboa: IICT; Arquivo Caculo Cacahenda, 2002.

7 Sobre a derrocada do Ndongo, cf. Beatrix Heintze, O fim do Ndongo com estado independente, in . Angola nos séculos XVI e XVII, Luanda: Editorial Kilombelombe, 2007, pp. 278-386. 
sobas aliados e/ou avassalados, as contendas e resistência dos ambundos, capitaneados por Jinga no Dongo e Matamba, e suas alianças com os povos jagas a Leste. Além do realce às estruturas político-sociais ambundas assentadas na religiosidade, tão importante é a apreciação da organização político-social dos jagas em seus quilombos, edificados sobre ritos de iniciação e sobre as leis da kizila, mas não em princípios linhageiros, diferentemente dos ambundos. Avessa aos intentos geopolíticos e mercantis portugueses, em sua tentativa de controlar as rotas de fornecimento de escravos, Jinga, personagem central do capítulo, abandona princípios linhageiros ambundos e, tal como salientou Linda Heywood, adere aos ritos jagas para com eles selar alianças, sobretudo com o poderoso Cassanje.

Nesse cenário em que as armas antecederiam a cruz devido ao fracasso da lusitanização do Congo quinhentista e da crescente demanda por cativos, as forças da então jaga Jinga se coligaram aos holandeses. Uma vez fortalecida, sua base religiosa foi a pedra angular para promover sua conversão aos rituais jagas, em negociação que implicou a incorporação e/ou o abandono de dados símbolos e rituais, inclusive de poder.

Assim, em exame que sublinha a interligação entre religiões e poder exclusivamente entre povos centro-africanos (ambundos e imbangalas), Marina de Mello e Souza interpreta fontes já muito manuseadas, mormente as narrativas de Cadornega,
Cortona, Battel, Cavazzi e Fernão de Sousa. Ela demonstra que, envolta até a alma em conflitos com os portugueses durante a primeira metade do século XVII, Jinga tornou-se "uma guerreira afamada pelo seu talento para a guerra e por suas capacidades mágicas, adquiridas junto aos jagas". $\mathrm{Na}$ ocasião, os jagas, é bom lembrar, eram então os mais temidos guerreiros da África Central Atlântica, quer por modo de vida baseado na guerra e no saque, quer pelos "seus poderes junto às forças invisíveis dos grandes chefes do passado" (p. 114).

Pelo exposto, aprendemos que a manipulação das estruturas cosmogônicas ambundas permitiu à Jinga alternar "suas identidades conforme as circunstâncias, transitando entre ngola do Dongo, portanto, ambunda, chefe jaga e tembanza, detentora de poderes especiais"; e, depois de idosa, cansada de guerrear como jaga, abandonada por Cassanje e baqueada pelos portugueses, tornar-se-ia "dona Ana de Sousa, cristã batizada e iniciada na religião dos brancos" (p. 141).

O capítulo 3 é um desdobramento do anterior, novamente com realce à personagem Ana de Sousa, que buscava a paz e desta vez instrumentalizou o catolicismo a seu favor, sem deixar de ser religiosamente ambunda, entretanto. Ademais de uma lição de método na lida com diferentes discursos coevos, o que repetidamente deve ser frisado, Marina de Mello e Souza enfatiza como os mesmos pensamentos religiosos que antes levaram Jinga em direção ao ritos jagas também 
viabilizaram conversão, politicamente estratégica, ao catolicismo. Aí, deve-se sublinhar o paralelismo traçado pela autora com a experiência do Congo de mais de um século antes. A tentativa de Jinga foi promover a "umbundização" de Matamba, o que gerou conflitos locais, mas também adesões. Novamente se fazem presentes as diferentes acepções e perspectivas sobre o sagrado suscitadas pela comparação. Em Matamba, o catolicismo jamais se converteu em religião de Estado ou serviu para legitimação do poder, ao contrário do que ocorrera no Congo. Logo, se houve aproximações entre as estruturas religiosas ambundas e conguesas, que permitiram a incorporação de elementos cristãos, não menos importantes foram as diferenças. Mas, em quaisquer casos, poder e religião estavam umbilicalmente interligados, até mesmo no post-mortem de Jinga - o que aproxima a análise de Souza à de Heywood quanto às batalhas em torno do funeral e da memória de Jinga.

Mas Souza salienta, ainda, a conversão católica do jaga Cassanje no pós-vida terrena de Jinga. Teria sido uma conversão estritamente voltada a fins mercantis para facilitar o escoamento de cativos para o tráfico. Seria uma adesão ao catolicismo muito diferente do efetivado no Dongo e no Congo, mas sem que o Cassanje deixasse de se apropriar de elementos cristãos. Em Matamba e em Cassanje, "o batismo dos chefes pareceu ser gesto eminentemente formal, com vistas a estabelecer relações de paz e de comércio com os portugueses" (p. 194). Há um claro contraste, no caso da Matamba de Jinga, com a análise de Linda Heywood, que aposta na conversão sincera da rainha, mesmo se feita de uma perspectiva religiosa ambunda.

Entretanto, quaisquer que fossem os catolicismos dos centro-africanos, o papel do clero católico, de catequistas, de mestres e de intérpretes foi fundamental. É o que a historiadora discute no capítulo 4, no qual sublinha as experiências de padres na lida com conflitos e aproximações entre dois sistemas religiosos, e entre os próprios sistemas centro-africanos. Aqui se visualizam as tensões entre membros do clero católico, especialmente entre jesuítas e capuchinhos. O envio dos capuchinhos pela Propaganda Fide, em 1645, foi uma tentativa de Roma para frear, ou melhor concorrer, com os amplos privilégios antes concedidos do padroado régio português, mas os africanos não foram personagens passivos neste processo. Ainda em 1618 e 1619, o monarca congolês d. Álvaro III (1616-1622) trocou por carta informações sobre os capuchinhos com o embaixador do Congo em Roma. Também solicitou ao papa Paulo V o envio de padres capuchinhos, o que redundou na primeira expedição destes padres ao Congo, em $1645 .{ }^{8}$ A busca de

8 Rosana Andréa Gonçalves, África Indômita: missionários capuchinhos no Reino do Congo (século XVII) (Dissertação de Mestrado, Universidade de São Paulo, 2008), pp. 39-40. 
autonomia se intensificou a partir de então. Porém, no Dongo e no Dembo, o catolicismo, precedido pelas armas, dobrou sobas e dembos e foi instrumento de domínio político português, ao passo que em Matamba, vimos, o poder de suas elites prescindiu do catolicismo, salvo as tentativas nesse sentido de dona Ana de Sousa, a antiga Jinga, nos derradeiros anos de sua vida.

Nessas distintas frentes, a autora analisa a atuação do clero europeu, especialmente os capuchinhos. Há na abordagem, no entanto, uma ausência do missionarismo jesuíta, também ausente na obra de Heywood. Os jesuítas são apenas lembrados sob a ótica dos capuchinhos, que sobre eles criaram imagens depreciativas. Os segundos seriam mais catequistas, os primeiros, mercadores. Os representantes da Propaganda Fide seriam mediadores entre mundos político-religiosos distintos, diplomatas, espécies de go-betweens..$^{9}$ Antes da chegada dos capuchinhos, todavia, foi o clero nativo (filhos das elites locais ou mestiços) que exerceu papel fundamental na vida político-religiosa, mediando conflitos, servindo como embaixadores de parte à parte, como conselheiros de poderosos africanos etc.

A autora estuda os dois sistemas religiosos (centro-africano e europeu)

9 Cf. o conceito em Alida Metcalf, Go-betweens and the Colonization of Brazil, 1500-1600, Texas: The University of Texas Press, 2005. com base em experiências de vida catequética de alguns padres. Perante a escassez documental, ela consegue tirar leite de pedra para perceber as vivências missionárias do filho da terra Dionísio Dias Barreto, do mestiço Calisto Zelotes dos Reis Magos, parte do clero local, ou do jesuíta Pedro Tavares, estrangeiro queimador de "ídolo." É um ótimo exemplo de história social do clero católico entre dois sistemas religiosos na África Central Atlântica seiscentista. E por meio destes fragmentos de trajetórias a autora interpreta as estruturas religiosas ambundas, as resistências religiosas centro-africanas, as expectativas do clero etc. No fim das contas, a exemplo da visitação pastoral do padre jesuíta Pedro Tavares, o tempo passava e tudo voltava a ser como antes, porque, em 1762, o "padre Manuel Ribeiro, ao percorrer os mesmos lugares, encontrou situação bastante semelhante" (p. 261). O batismo, a propósito, também continuava a ser significado a partir de diferentes perspectivas que não segundo a ortodoxia católica.

Além do Visivel revela os elos entre o mundo dos vivos e o dos mortos para a estruturação de sociedades centro-africanas, apontando os movimentos religiosos que tornaram o cristianismo multifacetado, quer fosse um cristianismo à frente das armas, quer fosse um que as antecedia, inclusive pelos ponto de vista africanos. Transladando-se dos valores religiosos ambundos e jagas, e destes ao cristianismo, a Jinga tanto de Linda Heywood como a de Marina de Mello e Souza 
é o maior exemplo de que fé, poder e comércio de cativos centro-africanos moldaram as histórias da África, visível e invisivelmente conectadas com o mundo atlântico por duas grandes historiadoras. Ambas, portanto, dão seguimento a uma linha de estudos que cada vez mais se consolida: a história do contato das religiões africanas com o cristianismo em África.

Igualmente, o comércio atlântico e interno de cativos foi o contexto da maior parte dos conflitos e convergências entre africanos e europeus na região, assunto amplamente estudado por diversos estudiosos, inclusive nas duas obras aqui resenhadas. Elas salientam que, no mais das vezes, o controle sobre rotas e áreas de "produção" de cativos na África Central, quer por parte dos europeus, quer por parte dos africanos, foi o principal motivo dos embates e alianças. Ainda que essas historiadoras não tragam novidades no que diz respeito a estes assuntos, nem por isso eles deixaram de ser contemplados na justa medida. O que não há, no entanto, é uma análise sobre como as estruturas políticas e religiosas centro-africanas também moldaram a escravidão e o comércio de cativos,${ }^{10}$ tendo em vista

10 A exemplo do que faz Harris Memel-Fôte, "Culture et nature dans les représentations africaines de l'esclavage et de la traite négrière. Cas des sociétés lignagéres“, in Isabel de Castro Henriques e Louis Sala-Molins (orgs.), Déraison, esclavage et droite. Les fondaments idéologiques e juridiques de la traite négreère et de l'esclavage. Col. Mémoire des peuples. La route de l'esclavage (Bruxelas: Éditions Unesco, 2002), pp. 195-202; idem, que, tal como a política, a economia não tinha uma esfera autônoma, não se explicava por si mesma, na África Central Atlântica ou alhures, na época moderna. ${ }^{11}$ Se o tráfico de cativos era o pano de fundo das relações de poder na África Central, qual o peso da religião para o entendimento do tráfico na perspectiva dos povos centro-africanos? As autoras não se dirigem a este tema crucial

Em ambos os livros, há outras lacunas: a missionação jesuíta; os motivos das desavenças políticas entre centro-africanos e suas próprias disputas em torno do controle do tráfico interno de cativos; a relação das chamadas guerras angolanas com as reorientações geopolíticas no Atlântico Sul, com a chamada viragem atlântica portuguesa na passagem da monarquia de Avis à dos Bragança, permeadas pela União Ibérica; e o diálogo com o revisionismo sobre a natureza do Estado Moderno (ambas as autoras ainda estão muito presas à ideia do Estado leviatã hobbesiano na abordagem do poder português na África em pauta).

Em suma, se as obras primam pela abordagem da política interna centro-africana, há silêncios sobre

«L'esclavage dans les sociétés lignagères de l'Afrique noire. Exemple de la Côte d'Ivoire précoloniale, 1700-1920» (Tese de doutorado, École des Hautes Etudes en Sciences Sociales, 1988).

11 Joseph Miller, Way of Death: Merchant Capitalism and the Angolan Slave Trade, 1730-1830, Madison: The University of Wisconsin Press, 1988; e Karl Polanyi, $A$ grande transformação: as origens de nossa época, 4a ed., Rio de Janeiro: Campus, 2000. 
a geopolítica do Atlântico Sul. Pelo menos se poderia sugerir algo sobre como essas dinâmicas se interligavam. Seria oportuno analisar como a conturbada conjuntura política dos séculos XVI e XVII na região foi importante tanto para a África Central e os centro-africanos, quanto para a formação do mundo atlântico. ${ }^{12}$ Faltou aqui um pouco de connected histories. Há, por fim, uma ausência que não é exclusiva desses dois títulos. Historiadores que lidam com a África Central Atlântica e África Ocidental quase não dialogam entre si, embora frequentemente tratem de temáticas afins.

Estou ciente, porém, de que as referidas lacunas se devem às escolhas das autoras de olhar com lupa para personagens e sociedades centro-africanas. A obra de Souza fornece uma visão de síntese comparativa, tendo o reino do Congo quinhentista como vetor do que sucedeu aos centro-africanos no Dongo e em Matamba seiscentistas - a análise secundariza a região do Dembo. Conclui que a pluralidade do cristianismo na região deriva das experiências malsucedidas da própria Igreja

12 John K. Thornton, Africa and the Africans in the Making of the Atlantic World, 14001800, Cambridge: Cambridge University Press, 1992; e sobretudo Luís Felipe de Alencastro, $O$ trato dos viventes: formação do Brasil no Atlântico Sul, São Paulo: Companhia das Letras, 2000. católica no Congo e, principalmente, dos modos pelos quais sociedades centro-africanos leram a nova religião. Talvez não se concorde integralmente com a hipótese porque há um esquematismo e uma linearidade na ideia de que, na passagem do século XVI para o XVII, a evangelização deu lugar às armas como principal estratégia de conquista portuguesa. Porém, a proposta é instigante.

Por sua vez, Linda Heywood optou pelos pormenores da história de vida de Jinga como fio condutor de uma análise que agrega religião, política, gênero e comércio de cativos na África Central. Estes aspectos são contemplados em minúcia no que talvez seja a mais completa biografia sobre Jinga até agora escrita, e engajada a ponto de a autora, às vezes, tomar partido pela personagem que estudou, uma vez Jinga buscava "recuperar o reino que the fora injustamente tirado", mas ela "ficaria orgulhosa dos membros da procissão fúnebre que fizeram a curta caminhada, carregando seu corpo numa cama [...]. Jinga não esperaria nada menos do que isso" (p. 138, 241, 243).

Exageros e lacunas à parte, o mérito desses livros é incontestável. Eles oferecem um quadro amplo da história das sociedades centro-africanas dos séculos XVI e XVII. São contribuições de peso para a historiografia da África, juntos ou separados.

Roberto Guedes

Universidade Federal Rural do Rio de Janeiro robertoguedesferreira@gmail.com 